\title{
Geographical origin of white honey produced by stingless bees in the Araucaria Forest in Southern Brazil
}

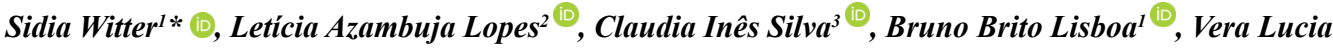 \\ Imperatriz-Fonseca ${ }^{4}$, Betina Blochtein ${ }^{5}{ }^{\circledR}$, Cláudio Augusto Mondin $^{5}$ \\ ${ }^{1}$ Secretaria de Agricultura Pecuária e Desenvolvimento Rural do Rio Grande do Sul, Departamento de \\ Diagnóstico e Pesquisa Agropecuária, Laboratório e Museu de Entomologia, Rua Gonçalves Dias n570, \\ Bairro menino Deus, CEP: 90130-060, Porto Alegre, RS, Brasil. \\ ${ }^{2}$ Universidade Luterana do Brasil, Programa de Pós Graduação em Ensino de Ciências e Matemática, Núcleo \\ de pesquisas em tecnologias Digitais no Ensino de Ciências, Av. Farroupilha, 8001, São José, Canoas, RS, \\ Brasil. \\ ${ }^{3}$ Universidade Federal de São Carlos-Campus de Sorocaba, Centro de Ciências e Tecnologias para a \\ Sustentabilidade, Rodovia João Leme dos Santos (SP-264), Km 110, Bairro do Itinga, Sorocaba, SP, Brasil. \\ ${ }^{4}$ Universidade de São Paulo, Instituto de Biociências, Rua do Matão, Trav. 14, $n^{\circ} 321$, Cidade Universitária, \\ CEP: 05508-090, São Paulo, SP, Brasil. \\ ${ }^{5}$ Pontificia Universidade Católica do Rio Grande do Sul, Escola de Ciências da Saúde e da Vida, Avenida \\ Ipiranga, 6681, Partenon, CEP: 90619-900, Porto Alegre, RS, Brasil \\ *Corresponding author: Sidia Witter, e-mail: sidia-witter@seapdr.rs.gov.br
}

WITTER, S., LOPES, L.A., SILVA, C.I., LISBOA, B.B., IMPERATRIZ-FONSECA, V.L., BLOCHTEIN, B., MONDIN, C.A. Geographical origin of white honey produced by stingless bees in the Araucaria Forest in Southern Brazil. 21(1): e20190925. . https://doi.org/10.1590/1676-0611-BN-2019-0925

Abstract: Honey produced by native stingless bees in the Araucaria Forest region of Rio Grande do Sul, southern Brazil, specifically the municipality of Cambara do Sul, is highly valued for its characteristic white color, floral odor and taste. In this study, we investigated the botanical origin of white honey stored in colonies of five Meliponini species of the genera Melipona $(\mathrm{n}=3)$ and Plebeia $(\mathrm{n}=2)$. During the production period of white honey, from January to March, flowers were sampled fortnightly along pre-established trails to identify plants used by bees. For all sampled plant species, exsiccates and pollen reference slides were prepared. Honey samples from stingless bees were processed for extraction and preparation of pollen grains for identification of pollen types. In all analyzed honey samples, pollen grains of Clethra scabra (Clethraceae) were predominant (between 46-94\%). Pollen grains from other botanical families, including Myrtaceae, Fabaceae and Melastomataceae were frequently identified in honey samples of the Melipona species, while Cunoniaceae was also found in samples of Plebeia species. In this study, we concluded that Clethra scabra is predominantly used by Meliponini bees in the production of white honey in the municipality of Cambará do Sul.

Keywords: bee flora; Clethra scabra; meliponiculture; Meliponini; pollen.

\section{Origem geográfica do mel branco produzido por abelhas sem ferrão na Floresta de Araucárias no Sul do Brasil}

Resumo: Na região da Floresta de Araucária do Rio Grande do Sul, especificamente no município de Cambará do Sul, as abelhas nativas sem ferrão produzem mel característico devido à sua cor branca e gosto apreciado. Neste estudo, investigamos a origem botânica do mel branco armazenado em colônias de cinco espécies de Meliponini dos gêneros Melipona $(\mathrm{n}=3)$ e Plebeia $(\mathrm{n}=2)$. Durante o período de produção do mel branco, de janeiro a março, as flores foram amostradas quinzenalmente ao longo de trilhas pré-estabelecidas, a fim de identificar as espécies utilizadas pelas abelhas. A partir de amostras de plantas foram preparadas exsicatas e lâminas de referência de pólen. As amostras de mel de abelhas sem ferrão foram processadas para extração e preparo dos grãos de pólen para a determinação dos tipos polínicos presentes. Em todas as amostras de méis branco analisadas os grãos de pólen de Clethra scabra (Clethraceae) predominaram (entre 46-94\%). Grãos de pólen de outras espécies das famílias botânicas Myrtaceae, Fabaceae e Melastomataceae foram frequentemente identificados nas amostras de méis das espécies de Melipona, enquanto Cunoniaceae também o foi nas amostras das espécies de Plebeia. Neste estudo, nós concluímos que Clethra scabra é predominantemente utilizada pelas abelhas Meliponini na produção de méis branco no município de Cambará do Sul.

Palavras-chave: Clethra scabra: flora apicola; meliponicultura; Meliponini: pólen 


\section{Introduction}

The Araucaria Forest is part of the Atlantic Forest biome, found in South and Southeast Brazil, and in the Argentinian province of Missiones (Backes \& Irgang 2002, Oliveira-Filho \& Fontes 2000). The total land area covered by this charismatic high altitude forest ecosystem has receded greatly in recent decades, as a consequence of anthropogenic activities, with remaining forest areas representing just $13 \%$ of its original coverage (Emer \& Fonseca 2011).

Land use change that causes loss and/or fragmentation of natural habitats negatively impacts native bees populations due to loss or change of the floral resources used as food sources and nesting sites (Kremen al. 2004). Stingless bees (Hymenoptera: Apidae: Meliponini) represent about $80 \%$ of the floral visitors of the upper stratum of the Atlantic Forest (Ramalho 2004). Therefore, alteration or loss of their populations affects the pollination of native plants (Kevan \& Baker 1983, Roubik 1989, Gruchowski-Woitowicz 2020) and the maintenance of regional biodiversity (Brown \& Albrecht 2001).

The management of stingless bees can provide rural communities with a sustainable source of income, and promote wider ecosystem restoration (Venturieri et al. 2012). The market for honey produced by stingless bees has grown rapidly in recent years, and is commonly sold at a higher price per kilo than honey produced by Apis mellifera Linnaeus, 1758 (Souza et al. 2006). Stingless bee honey occupies a specific niche in the market due to its appeal to consumers interested in healthy living, social justice and sustainable production with native species. However, the production of honey from stingless bees is still incipient and only serves local markets (Alves 2013).

The characteristics of stingless bees' products are closely related to local abiotic (e.g., climate) and biotic variables (e.g., plant community composition, bee species' physiology and life history strategy) (Lira et al. 2014). Knowledge on the botanical origin and the physicochemical properties of honey add value to it (Aboud et al. 2011) and allow the management of the flora and the hives for its production. Pollen analysis can be used to characterize the botanical and geographical origin of honey (Barth 1989), since the composition of the bee pollen differs according to the region or season, indicating patterns and variations of the local flora (Barth 2004). In the northeast of the Rio Grande do Sul State, in the Araucaria Forest ecosystem, Apis mellifera produces characteristic honey, called white honey, which has a very particular floral flavor and odor (Cambará do Sul 2020). Stingless bees also produce this "white honey", but in both cases, the botanical origin and potential bee species that produce the white honey, considered a local delicacy, remain poorly understood.

The aim of this study was to identify the floral resources used by stingless bees in the production of white honey in the Araucaria Forest of the Rio Grande do Sul State. The results of this study will benefit regional meliponiculturists, adding value to the honey by providing knowledge of its botanical origin, and guiding hive management in the areas with the flowers detected in this melissopalynological analysis.

\section{Material and Methods}

\section{Area of study}

The study was performed in an area of 250 ha located in the municipality of Cambará do Sul (2902' 51 S $\left.^{\prime} 50^{\circ} 08^{\prime} 40 \mathrm{~W}^{\prime}\right)$, Northeast region of Rio Grande do Sul state, Brazil, with altitudes ranging from 980 to $1047 \mathrm{~m}$ (Figure 1). The climate of the region is predominantly $\mathrm{Cfb}$ (Köppen classification), temperate humid (Boldrini 2009). Mixed Ombrophilous Forest is characterized by a rich floristic mixture and physiognomy, evident by the presence of Araucaria angustifolia (Brazilian pine) of in the upper canopy and with a species-rich forest understory (Veloso et al. 1991, Jarenkow \& Budke 2009).

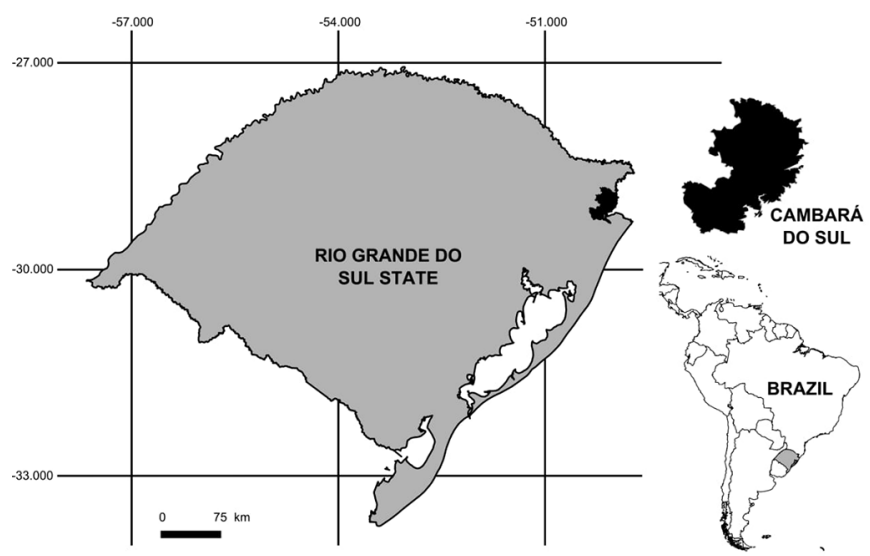

Figure 1. Municipality of Cambará do Sul, RS, Brazil, site of white honey production.

\section{Plant collection and pollen preparation}

In 2008, during the region's peak white honey production period (January to March), flowering plants were collected and the exsiccates prepared to identify the botanical species as potential food sources for bees. Flower buds were packed in paper envelopes to prepare the regional pollen reference collection for comparison with pollen types collected in bee honey samples. Collections were carried out fortnightly along two $2 \mathrm{~km}$ trails, both in rural areas and forest edges.

Plants were identified by experts and deposited in the herbarium of the Department of Diagnosis and Agricultural Research (DDPA) of the Secretariat for Agriculture, Livestock and Rural Development of Rio Grande do Sul and the Herbarium of the Pontifical Catholic University of Rio Grande do Sul (PUCRS). The reference slides were prepared by removing the pollen grains from the anthers according to protocol presented by Silva et al. (2014) and subsequently submitted to the acetolysis method (Erdtman, 1960). Three slides were assembled from each plant sample, which was cataloged and deposited in the Museum of Entomology of the Department of Diagnosis and Agricultural Research (DDPA) of the Secretariat for Agriculture, Livestock and Rural Development of Rio Grande do Sul and duplicate of these slides in the Palynological Laboratory of FFCLRP-USP (Faculty of Philosophy, Sciences and Letters at Ribeirão Preto, University of São Paulo). Images of each pollen type were obtained with a camera attached to the optical microscope Leica DM4000B that allowed an increase of up to 2560x.

\section{Honey harvest}

In 2008 and 2009, from January to March, thirty-three samples of honey were obtained from nine (9) Meliponini hives of five species: Melipona bicolor schencki Gribodo, $1893(\mathrm{n}=4)$, Melipona torrida Friese, $1916(\mathrm{n}=2)$, Melipona quadrifasciata quadrifasciata Lepeletier, $1836(\mathrm{n}=1)$, Plebeia remota (Holmberg, 1903) $(\mathrm{n}=1)$ and Plebeia 
emerina (Friese, 1900) $(\mathrm{n}=1)$. From these species, nineteen (19) samples were obtained from the hives of Melipona bicolor schencki, eight (8) from Melipona torrida, two (2) from Melipona quadrifasciata quadrifasciata, two (2) from Plebeia remota and two (2) from Plebeia emerina. The honey was collected with the aid of disposable pippetes.

\section{Pollen analyses}

Pollen types present in the honey samples were identified by morphological comparison to the reference collection of the Palynological Laboratory of FFCLRP-USP. Honey samples were prepared firstly according to the methodology described in Rezende et al. (2020), where $10 \mathrm{ml}$ of each honey sample was diluted in $20 \mathrm{ml}$ of distilled water and centrifuged to separate pollen grains. Afterward, the samples were submitted to the acetolysis method and pollen grains were mounted using glycerinated gelatin on sets of three slides sealed with paraffin (Kisser 1935). For the quantitative analysis, 400 pollen grains per sample were counted and were grouped according to the frequency class definition following the adaption by Santos et al. (2012) of the methodology in of Louveaux et al. (1978): predominant pollen ( $>45 \%$ ); secondary pollen $(\leq 45 \%$ to $>15 \%)$; important minor pollen $(\leq 15 \%$ to $\geq 3 \%$ ); and minor pollen $(<3 \%)$. These analyses were carried in the Palynological Laboratory of FFCLRP-USP.

\section{Results}

During the white honey production period, 19 flowering plant species belonging to 12 botanical families were registered. Myrtaceae showed the highest richness (five taxa), followed by Asteraceae (three taxa) and Cunoniaceae (two taxa). However, only pollen grains from six (6) of these families were detected in honey samples. Nonetheless, pollen grains from a further nine (9) botanical families not detected in plant surveys were also found in honey samples (Table 1).

In relation to the samples of white honey, 36 pollen types were detected and distributed among 15 plant families (Table 1). The family Myrtaceae (10) was the richest in pollen types followed by Fabaceae (5), Arecaceae (3), Melastomataceae (3) and Solanaceae (3).

The predominant pollen type (DP) in all honey samples analyzed belonged to the Clethraceae family, with only one pollen type, Clethra scabra (Figure 2) with percentages above $45 \%$. The size of the pollen grain (Figure 3 ) of this plant is classified as very small $(<10 \mu \mathrm{m})$ and its occurrence in honey indicates a strong nectar collection from its flowers. This honey is colorless white or cloudy white to amber when crystallized. Although in Melipona quadrifasciata quadrifasciata honey the proportion of Clethra scabra pollen (46.5\%) was lower than Fabaceae pollen (47.37\%), both families are categorized as predominant pollen (Figure 2).

Myrtaceae was distinguished as important secondary pollen (IIP) in Melipona torrida and Melipona bicolor schencki honey, and Cunoniaceae as important minor pollen (AP) in the samples of Plebeia remota and as important minor pollen (IIP) in the samples of Plebeia emerina (Figure 2). Another botanical family with important participation in Melipona torrida and Melipona quadrifasciata quadrifasciata honey was Melastomataceae (Figure 2).

Although Melipona bicolor schencki honey presented 22 pollen types, Clethraceae and Myrtaceae together represent $98.5 \%$ of the pollen samples. In Melipona torrida honey, the same number of pollen types was found (22) but the contribution of other families was higher, as well as in Melipona quadrifasciata quadrifasciata honey (Table 2).

The bee species most faithful to Clethra scabra flowers was Melipona bicolor schencki during the two years of study (Figure 4). Species of Plebeia used a higher percentage of Clethra scabra in 2008 and Melipona torrida in 2009 (Figure 4). Honey samples from Melipona quadrifasciata quadrifasciata were collected only in 2008.

\section{Discussion}

Clethra scabra pollen was numerically predominant in all honey samples of the five Meliponini species analyzed, except $M$. quadrifasciata. This species blooms during January and February and, according to Ramalho (2004), the pollen and nectar of its flowers were used by bees as food resources, thus confirming its strong melitophile character. Honey samples from Melipona bicolor schencki contained the highest proportion of C. scabra pollen. Despite the importance of Clethra scabra as a food resource for bees in the summer, other plant families, including Myrtaceae, Fabaceae and Melastomataceae also represented important food resources for the three species of Melipona, while Cunoniaceae was mainly used by the two species of Plebeia to meet colony nutritional demands. The number of pollen grains of plants with poricidal anthers, such as the Clethraceae and Melastomataceae, could be an effect of intranidal contamination. In the discussion presented by Maia-Silva et al. (2020), the authors mentioned that Melipona nests usually present fewer pollen storage pots than honey pots, and that during the mass flowering the bees foraging activity suddenly increases. Then, pollen foragers may not find appropriate storage space, and so deposit their load in any available pots. This behavior seems to be normal to Melipona since it has observed several species occurring in different regions (Alves et al., 2012; Nascimento and Nascimento 2012; Maia-Silva et al. 2014, 2016).

Lopes (2012) studied the floristic composition and floral phenology in the same area of study and identified 60 species of flowering plants from January to March and observed that Asteraceae was the richest family by number of species, followed by Myrtaceae, Fabaceae and Melastomataceae. For Melipona species, the importance of Myrtaceae, Fabaceae and Melastomataceae seems to be related to the richness of flowering species during this period. However, in the present study, Meliponini showed a clear preference for Clethra scabra, that besides providing pollen, also produces a high volume of nectar, the most attractive resource for the Meliponini bees.

One possible factor which could explain the preference of Melipona species for flowers of Clethra scabra is the presence of poricidal anthers, characteristic of this genus (Rossi 1992). Flowers with these characteristics need agents of pollination capable of vibrating the anthers to remove pollen, and Melipona exhibits this behavior (Ramalho et al. 1989). Pollen grains from other species with poricidal anthers as of Melastomataceae were also found in the honey produced by Melipona bees (Table 1).

Studies performed in the Atlantic Forest in Rio Grande do Sul, in regions close to the studied area, did not mention visits to flowers of Clethra scabra by Melipona bicolor schencki (Wilms \& Wiechers 1997) and Melipona torrida (Hilgert-Moreira et al. 2014). There was also no record of production of the characteristic white honey. Meliponini exhibit high levels of floral constancy, where foraging individuals 
Witter, S. et al.

Table 1. Flowering plants detected in the white honey production period (January-March 2008, 2009) and pollen types present in stingless bee honey, Cambará do Sul, RS, Brazil.

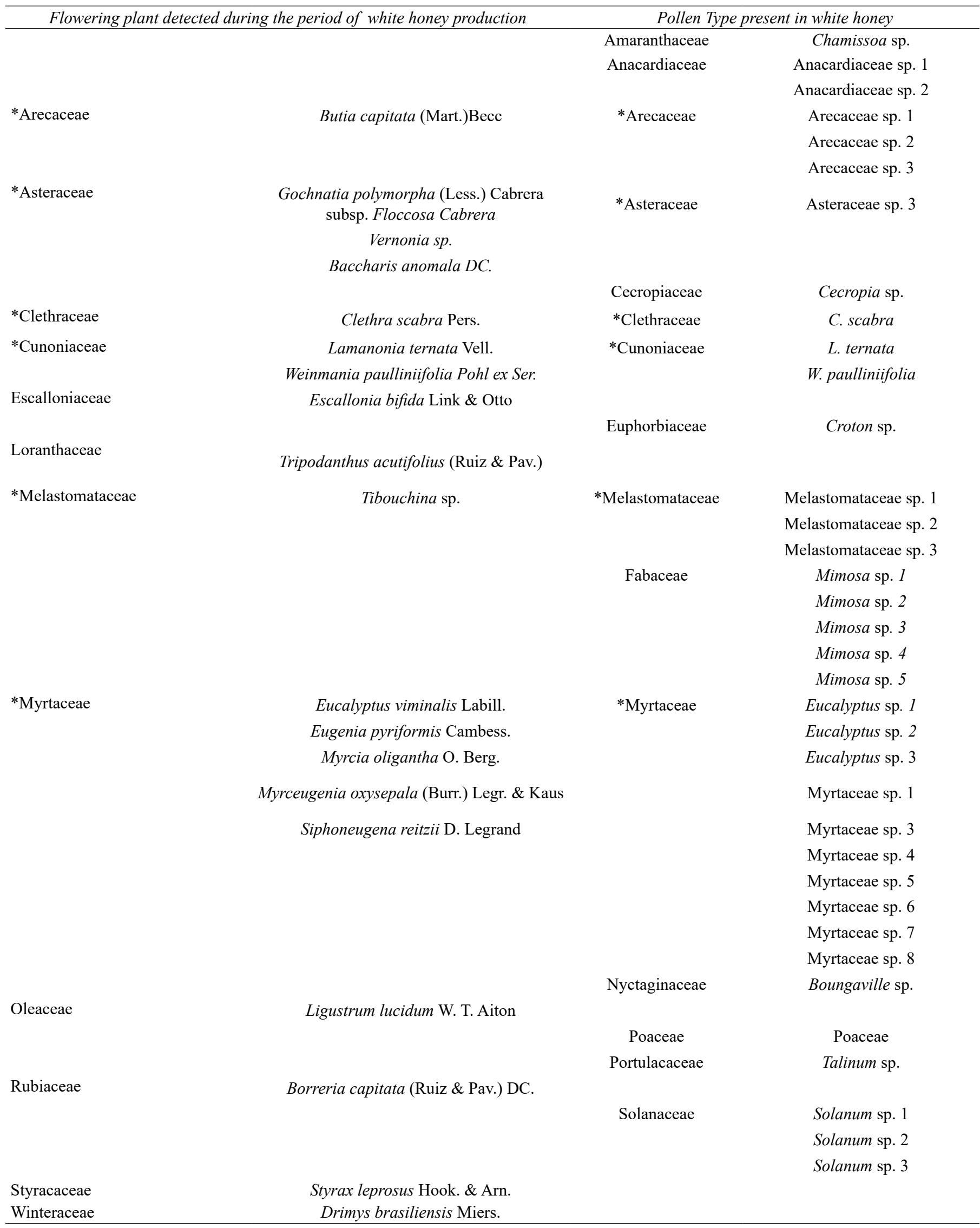



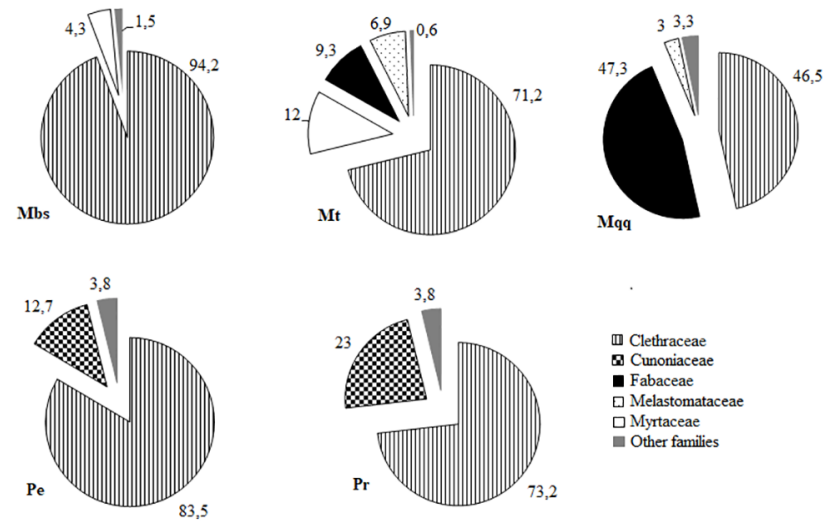

Figure 2. Average percentage of pollen types of the botanical families present in samples of Meliponini honey obtained in Cambará do Sul, RS, Brazil, in 2008/2009. Melipona bicolor schencki (Mbs); Melipona torrida (Mt); Melipona quadrifasciata quadrifasciata (Mqq); Plebeia emerina (Pe); Plebeia remota (Pr).

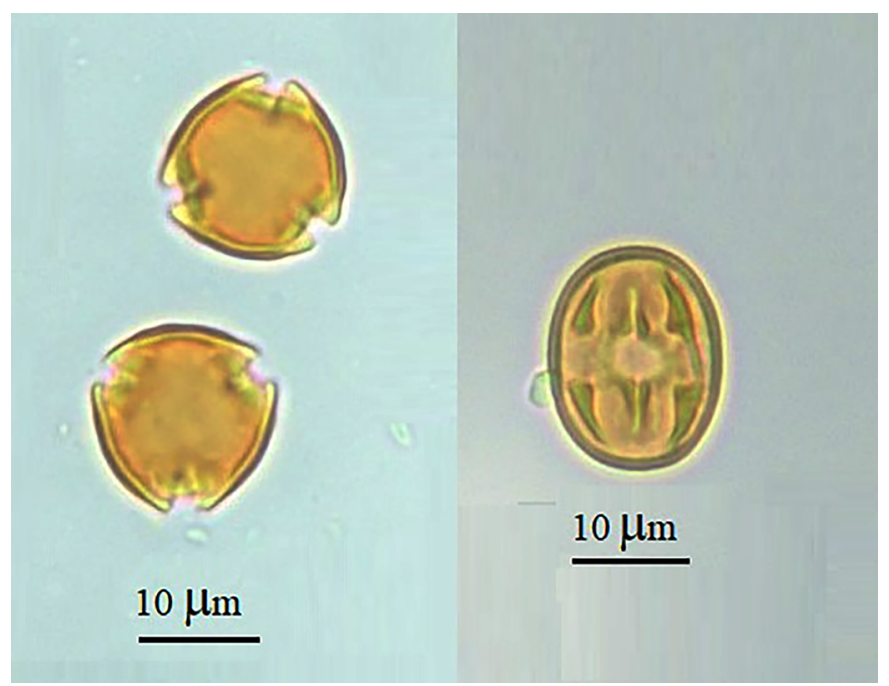

Figure 3. Clethra scabra pollen grains in polar (left) and equatorial (right) views.

visit only one type of flower during the same foraging trip (Ramalho et al. 1994).

White honey is referred to as a rare product with particular floral flavor and odor that makes it a delicacy in the study region. The high percentage of pollen grains of Clethra scabra signifies that this Meliponini honey can be classified as unifloral or monofloral.

This study provides empirical evidence for the processes of geographical indication and Denomination of Origin (DO) to white honey from Cambará do Sul/RS. Geographical indications are collective tools for valuing traditional products linked to certain territories. They have two functions: to add value to the product and to protect the producing region. The DO defines that a particular area has a product whose qualities have exclusive or essential influence because of the characteristics of that place, including natural and human factors (Giesbrecht et al. 2011).
The valuation of white honey of Clethra scabra and, consequently, the bee species associated with its production constitute an opportunity for its conservation, since the plant and some bee species that produce this honey, are on the list of endangered species of Rio Grande do Sul (Fundação Zoobotânica 2012).

\section{Conclusions}

- Clethra scabra was the dominant plant species in all honey samples confirming the indication of this plant to beekeepers for the white honey production;

- The high percentage of Clethra scabra pollen grains characterize the honey analyzed as unifloral;

- Melipona bicolor schencki was the most specialized stingless bee species in the collection of Clethra scabra.

\section{Acknowledgements}

Sélvio de Macedo Carvalho and Neura Carvalho, for providing the area, honey samples and support during the development of this study; Alistair J. Campbell for language support, and MCTIC /CNPq- Brazil 312250/2008-5 for VLIF.

\section{Author Contributions}

Sidia Witter: Substantial contribution to the conception and design of the work; Contribution to data acquisition; Contribution to data analysis and interpretation; Contribution to the writing of the work; Contribution to critical review by adding intellectual content.

Letícia Azambuja Lopes: Substantial contribution to the conception and design of the work; Contribution to data acquisition; Contribution to data analysis and interpretation; Contribution to the writing of the work; Contribution to critical review by adding intellectual content.

Cláudia Inês Silva: Substantial contribution to the conception and design of the work; Contribution to data acquisition; Contribution to data analysis and interpretation; Identification of the botanical origin pollen morphology description; Contribution to the writing of the work; Contribution to critical review by adding intellectual content.

Bruno Brito Lisboa: Substantial contribution to the conception and design of the work; Contribution to data acquisition; Contribution to data analysis and interpretation; Contribution to the writing of the work; Contribution to critical review by adding intellectual content.

Vera Lucia Imperatriz-Fonseca: Substantial contribution to the conception and design of the work; Contribution to critical review by adding intellectual content.

Betina Blochtein: Substantial contribution to the conception and design of the work; Contribution to data acquisition; Contribution to data analysis and interpretation; Contribution to the writing of the work; Contribution to critical review by adding intellectual content.

Cláudio Augusto Mondin: Substantial contribution to the conception and design of the work; Contribution to data acquisition; Contribution to data analysis and interpretation; Contribution to the writing of the work; Contribution to critical review by adding intellectual content. 
Witter, S. et al.

Table 2. Relative frequency (\%) of pollen types in stingless bees honey, in Cambará do Sul, RS, Brazil, in 2008/2009. Pollen frequency (PF); Species / pollen types (PT); Melipona bicolor schencki (Mbs); Melipona torrida (Mt); Melipona quadrifasciata quadrifasciata (Mqq); Plebeia emerina $(\mathrm{Pe})$; Plebeia remota $(\mathrm{Pr})$.

\begin{tabular}{|c|c|c|c|c|c|c|c|c|c|c|}
\hline & \multicolumn{2}{|c|}{ Mbs } & \multicolumn{2}{|c|}{ Mt } & \multicolumn{2}{|c|}{ Mq } & \multicolumn{2}{|c|}{$\mathrm{Pe}$} & \multicolumn{2}{|c|}{ Pr } \\
\hline & PF & PT & PF & PT & PF & PT & PF & PT & PF & PT \\
\hline Amaranthaceae & 0 & 0 & 0 & 0 & 0 & 0 & 1 & 1 & 0 & 0 \\
\hline Arecaceae & 0 & 0 & 0,1 & 2 & 0,5 & 1 & 0,3 & 1 & 0,25 & 1 \\
\hline Asteraceae & 0 & 0 & 0 & 0 & 0 & 0 & 0 & 0 & 0,1 & 1 \\
\hline Cunoniaceae & 0,39 & 2 & 0,3 & 2 & 0,1 & 1 & 12,7 & 1 & 23 & 2 \\
\hline Euphorbiaceae & 0 & 0 & 0 & 0 & 0 & 0 & 0,1 & 1 & 0 & 0 \\
\hline Fabaceae & 0,1 & 1 & 9,3 & 5 & 47,3 & 5 & 0,5 & 1 & 0,5 & 1 \\
\hline Melastomataceae & 0,7 & 3 & 6,9 & 2 & 3 & 2 & 0 & 0 & 0 & 0 \\
\hline Portulaceae & 0 & 0 & 0,02 & 1 & 0,1 & 1 & 1 & 0 & 0 & 0 \\
\hline Solanaceae & 0,1 & 3 & 0,04 & 1 & 0 & 0 & 0 & 0 & 0,75 & 0 \\
\hline Undetermined & 0,01 & 1 & 0 & 0 & 0 & 0 & 0,1 & 1 & 0 & 0 \\
\hline $\begin{array}{c}\text { Total Pollen } \\
\text { Types }\end{array}$ & & 22 & & 22 & & 16 & & 11 & & 10 \\
\hline
\end{tabular}

m Clethraceae Cunoniaceae $\square$ Fabaceae $\square$ Melastomataceae $\square$ Myrtaceae $\square$ Otherfamilies
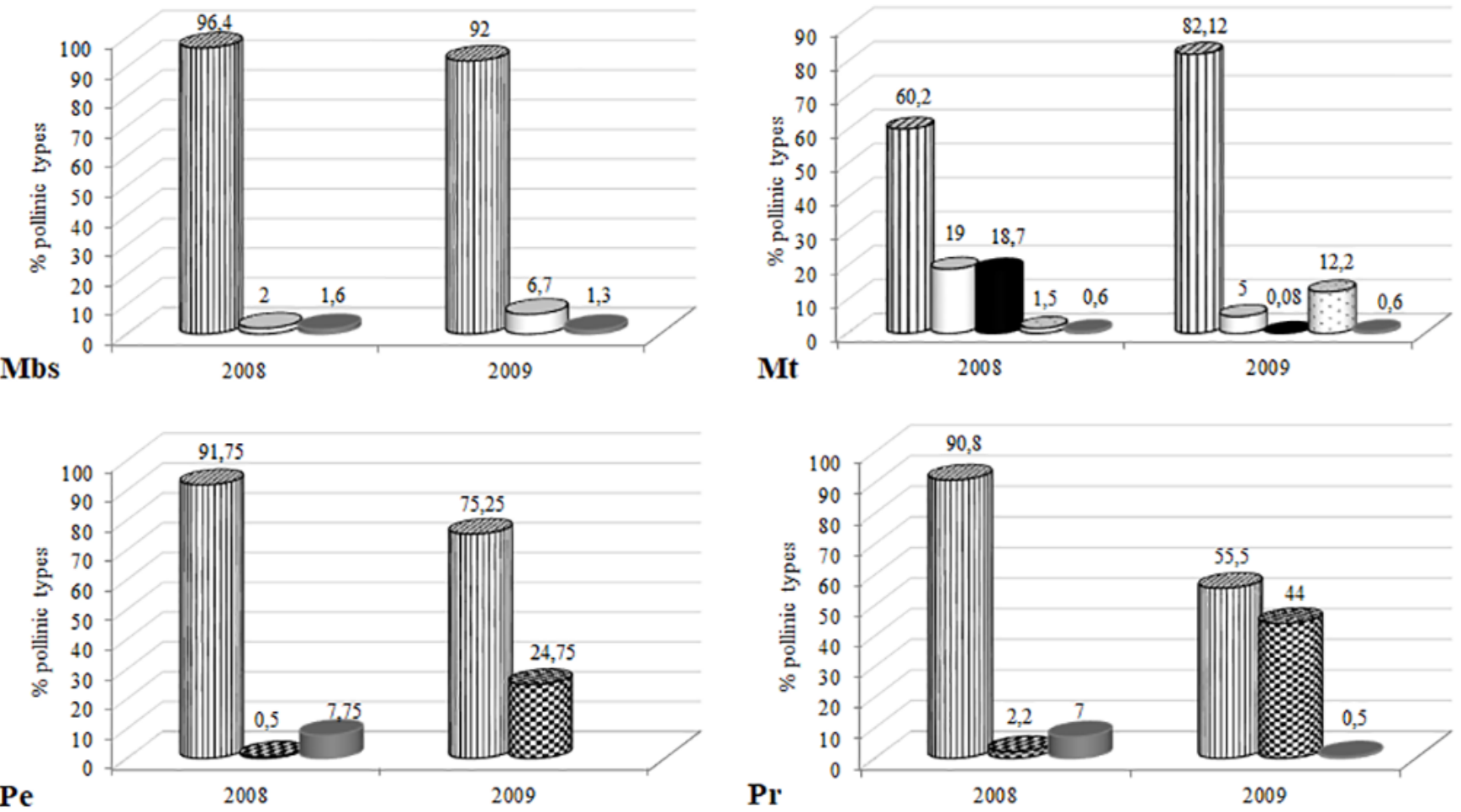

Figure 4. Proportion of botanical families of the pollen grains present in honey of stingless bees Melipona bicolor schencki (Mbs); Melipona torrida (Mt); Plebeia emerina (Pe); Plebeia remota (Pr), in Cambará do Sul, RS, Brazil, in 2008 and 2009. 


\section{Conflicts of interest}

The authors declare no competing interests.

\section{References}

ABOUD, F., DE PASQUALE, C., SINACORI, A., MASSI, S., CONTE, P. \& ALONZO, G. 2011. Palynological, physico-chemical and aroma characterization of Sicilian honeys. JAAS. 3(4): 164 - 173.

ALVES, R.M.O., CARVALHO, C.A.L., FAQUINELLO, P., LEDO, C.A.S., FIGUEREDO, L. 2012. Parâmetros biométricos e produtivos de colônias de Melipona scutellaris Latreille, 1811 (Hymenoptera: Apidae) em diferentes gerações. Magistra 24:105-111.

ALVES, R.M.O. 2013. Production and marketing of Pot-Honey. In Pot-Honey: The legacy of stingless bees ( P. Vit., S. Pedro \& D. H .Roubik, eds). Springer, New York, Chap. 40, p. 153-171.

BACKES, P. \& IRGANG, B. 2002. Árvores do Sul. Guia de identificação e interesse ecológico. Instituto Souza Cruz, Santa Cruz do Sul.

BARTH, O.M. 1989. O pólen no mel brasileiro. Editora Luxor, Rio de Janeiro.

BARTH, O.M. 2004. Melissopalynology in Brazil: a review of pollen analysis of honeys, propolis and pollen loads of bees. Sci. Agric. 61: 342-350.

BOLDRINI, I. L. 2009. Biodiversidade dos Campos do Planalto das Araucárias. MMA, Brasília.

BROWN, C. J. \& ALBRECHT, C. 2001. The effect of tropical deforestation on stingless bees of the genus Melipona (Insecta: Hymenoptera: Apidae: Meliponini) in central Rondonia, Brazil. J. Biogeogr. 28: 623-634.

CAMBARÁ DO SUL. Assembleia Legislativa. Projeto de Lei $\mathrm{n}^{\circ}$ 56/2020. Declara o Município de Cambará do Sul como a Capital do Mel de Florada Nativa. http://www.al.rs.gov.br/agenciadenoticias/destaque/tabid/855/ Default.aspx?IdMateria=322000 (último acesso em 21/09/2020).

EMER, C. \& FONSECA, C.R. 2011. Araucaria Forest conservation: mechanisms providing resistance to invasion by exotic timber trees. Biol. Invasions. 13: $189-202$.

ERDTMAN, G. 1960. The acetolysis method. A revised description. Svensk Bot Tidskr, 54:561-564.

FUNDAÇÃO ZOOBOTÂNICA. Lista das espécies da flora nativa ameaçadas de extinção no Estado do Rio Grande do Sul. https://secweb.procergs.com.br/ livlof/?id_modulo=2\&id_uf=23\&ano=2013 (último acesso em 15/09/2020).

FUNDAÇÃO ZOOBOTÂNICA. Lista das espécies da Fauna ameaçada de extinção no Estado do Rio Grande do Sul. https://secweb.procergs.com.br/ livlof $/$ id_modulo $=1 \&$ id_uf $=23 \&$ ano $=2012$

(último acesso em 30/10/2020).

GIESBRECHT, H.O., MINAS, R. B. A., GONÇALVES, M.F.W., SCHWANKE, F.H. 2011. Indicações geográficas brasileiras. SEBRAE, Brasília.

Gruchowski-Woitowicz, F.C., da Silva, C.I. and Ramalho, M. (2020), Experimental field test of the influence of generalist stingless bees (Meliponini) on the topology of a bee-flower mutualistic network in the tropics. Ecol Entomol, 45: 854-866. https://doi.org/10.1111/een.12862

HILGERT-MOREIRA, S.B., NASCHER, C.A., CALLEGARI-JACQUES, S. M., BLOCHTEIN, B. 2014. Pollen resources and trophic niche breadth of Apis mellifera and Melipona obscurior (Hymenoptera, Apidae) in a subtropical climate in the Atlantic rain forest of southern Brazil. Apidologie. 45:129-141.

JARENKOW, J.A. \& BUDKE, J.C. 2009. Padrões florísticos e análise estrutural de remanescentes de Florestas com Araucária no Brasil. In FONSECA, C.R.et al. Floresta com Araucária: ecologia, conservação e desenvolvimento sustentável. Editora Holos, Ribeirão Preto, p. 113-126.

KEVAN, P.G. \& BAKER, H.G. 1983. Insects as flower visitors and pollinators. Annu. Rev. Entomol. 28: 407-453.

KISSER, J. 1935. Bemerkungen Zum Einschluss in glycerim. Berlim: Z. Wiss.
KREMEN C., WILLIAMS, N.M., BUGG, R.L., FAY, J. P., THORP, R. W. 2004. The area requirements of an ecosystem service: crop pollination by native bee communities in California. Ecol Lett. 7: 1109-1119.

LIRA, A.F., MELLO SOUSA, J.P.L., LORENZON, M.C.A., VIANNA, C.F.A.J., CASTRO, R.N. 2014. Estudo comparativo do mel de Apis mellifera com méis de meliponíneos. Acta Vet Bras. 8(3):169-178.

LOPES, L.A. 2012. Abelhas sem ferrão em fragmentos preservados de floresta com Araucária em Cambará do Sul, RS, com ênfase em Melipona bicolor schencki. 140p. Thesis, University of São Paulo, Ribeirão Preto

LOUVEAUX, J., MAURIZIO, A., VORWOHL, G. 1978. Methods of melissopalynology. Bee World. 59:139-157.

MAIA-SILVA, C., IMPERATRIZ-FONSECA, V.L., SILVA, C.I., HRNCIR, M. 2014. Environmental windows for foraging activity in stingless bees, Melipona subnitida Ducke and Melipona quadrifasciata Lepeletier (Hymenoptera: Apidae: Meliponini). Sociobiology 61:378-385.

MAIA-SILVA C, HRNCIR M, IMPERATRIZ-FONSECA VL, SCHORKOPF DLP. 2016. Stingless bees (Melipona subnitida) adjust brood production rather than foraging activity in response to changes in pollen stores. J Comp Physiol A 202:723-732.

MAIA-SILVA, C., LIMÃO, C.C., SILVA, C.I., IMPERATRIZ-FONSECA, V.L., HRNCIR, M. 2020. Stingless Bees (Melipona subnitida) Overcome Severe Drought Events in the Brazilian Tropical Dry Forest by Opting for High-Profit Food Sources. Neotrop Entomol. https://link.springer.com/ article/10.1007/s13744-019-00756-8 (último acesso em 12/06/2020).

NASCIMENTO, D.L., NASCIMENTO, F.S. 2012. Extreme effects of season on the foraging activities and colony productivity of a stingless bee (Melipona asilvai Moure, 1971) in northeast Brazil. Psyche, 2012:1-6.

OLIVEIRA-FILHO, A.T. \& FONTES, M. A. L. 2000. Patterns of floristic differentiation among Atlantic Forests in southeastern Brazil and the influence of climate. Biotropica. 32(4b): 793-810.

RAMALHO, M. 2004.Stingless bees and mass flowering trees in the canopy of Atlantic Forest: a tight relationship. Acta Bot. Bras. 18:37-47.

RAMALHO, M., GIANNINI, T.C., MALAGODI-BRAGA, K.S., IMPERATRIZFONSECA, V.L.1994. Pollen harvest by stingless bee foragers (Hymenoptera, Apidae, Meliponinae). Grana. 33: 239-244.

RAMALHO, M., KLEINERT, A.M.P.; IMPERATRIZ-FONSECA, V.L. 1989. Utilization of floral resources by species of Melipona (Apidae, Meliponinae): floral preferences. Apidologie. 20:185-195.

REZENDE, A.C.C., ABSY, M.L., FERREIRA, M.G., MARINHO, H.A. 2020. Honey botanical origin of stingless bees (Apidae Meliponini) in the Nova America community of the Sateré Mawé indigenous tribe, Amazon, Brazil. Grana, DOI: 10.1080/00173134.2020.1724323 (último acesso em 01/06/2020).

ROSSI, L. Clethraceae. 1992. In: Flora Fanerogâmica da Ilha do Cardoso (São Paulo, Brasil) (M.M.R.F. Melo, F. Barros, S.A.C. Chiea, M.G.L. Wanderley, S.L. Jung-Mendaçolli \& M. Kirizawa eds). Instituto de Botânica USP, São Paulo, 3: 69-71.

ROUBIK, D.W. 1989.The Ecology and Natural History of Tropical Bees. University Press, Cambridge.

SANTOS, F.A.R., NOVAES, D.M., QUEIROZ, L.P. 2012. Pollen of Bauhinia L. and Phanera Lour. (Leguminosae-Caesalpinioideae) from the Brazilian Caatinga. Ame J Plant Sci, 3:909-920.

SILVA, C. I. 2014. Catálogo polínico das plantas usadas por abelhas no campus da USP de Ribeirão Preto. Holos: Ribeirão Preto.

SOUZA, B., ROUBIK, D., BARTH, O., HEARD, T., ENRÍQUEZ, E., CARVALHO, C., VILLAS-BÔAS, J., MARCHINI, L., LOCATELLI, J., PERSANO-ODDO, L. 2006. Composition of stingless bee honey: setting quality standards. Interciência. 31(12): 865-875.

VELOSO, H.P., RANGEL-FILHO, A. L R., LIMA, J.C.A. 1991.Classificação da vegetação brasileira adaptada a um sistema universal. IBGE, Rio de Janeiro. 
Witter, S. et al.

VENTURIERI, G.C., ALVES, D.A., KAHN, J., VILlAS-BÔAS, J., CARVALHO, C.A.L., MENEZES, C., VOLLET-NETO, A., CONTRERA, F.A.L., CORTOPASSI-LAURINO, M., NOGUEIRA-NETO, P., IMPERATRIZ-FONSECA, V.L. 2012. Meliponicultura no Brasil: situação atual e perspectivas futuras. In: Polinizadores no Brasil: contribuição e perspectivas para biodiversidade, uso sustentável, conservação e serviços ambientais. (V.L. Imperatriz Fonseca., D.A.L. Canhos., D.A. Alves \& A.M. Saraiva, eds). EDUSP, São Paulo, p. 213-236.
WILMS, W. \& WIECHERS, B. 1997. Floral resource partitioning between native Melipona bees and the introduced Africanized honeybee in the Brazilian Atlantic rain forest. Apidologie 28: 339-355.

Received: $22 / 11 / 2019$

Revised: 13/11/2020

Accepted: 23/11/2020

Published online: 18/01/2021 